\title{
Recovery from pulmonary hypertension in an adolescent with mixed connective tissue disease
}

\author{
Deborah M Friedman, Hal J Mitnick, Delores Danilowicz
}

\begin{abstract}
This paper describes the case of an 11 year old girl who presented with mixed connective tissue disease which was complicated by the development of pulmonary hypertension. This case is unique with respect to the young age of onset, the serial non-invasive method used to follow the disease process, and the favourable response to treatment with vasodilator and anti-inflammatory drugs.
\end{abstract}

(Ann Rheum Dis 1992; 51: 1001-1004)

Pulmonary hypertension is a serious and baffling clinical problem, the optimum evaluation of which still eludes definition and the treatment of which is largely empirical. Secondary pulmonary hypertension may result from a variety of cardiac, pulmonary, or systemic diseases, or may present as an apparently primary disease with a predominantly arteriopathic, veno-occlusive or thromboembolic nature. Often life threatening in severity, the disease begins subtly in a poorly accessible site so that optimum diagnostic evaluation is delayed and difficult and treatment is still not fully defined. This problem has now become more widely recognised in children. ${ }^{1}$

Mixed connective tissue disease is an autoimmune disease rarely seen in children, ${ }^{2}$ but which is known to be associated with the development of pulmonary hypertension, ${ }^{3-5}$ which usually carries an unfavourable prognosis. This paper describes an 11 year old girl with mixed connective tissue disease who developed well documented pulmonary hypertension and who responded to aggressive treatment with apparent pulmonary vascular recovery.

Division of

Pediatric Cardiology,

New York University

Medical Center,

New York, NY, USA

D M Friedman

D Danilowicz

Division of

Rheumatology,

New York University

Medical Center,

New York, NY, USA

H J Mitnick

Correspondence to:

Dr Deborah M Friedman, Division of

Pediatric Cardiology,

New York University

Medical Center,

550 First Avenue

New York, NY 10016, USA.

Accepted for publication

15 October 1991

\section{Case report}

An 11 year old Asian girl presented with mixed connective tissue disease, including fever, swollen hands, Raynaud's phenomenon, pleuro/ pericarditis, Coombs' positive anaemia, lymphadenitis and parotitis, circulating anticoagulant, restrictive lung disease, and intermittent changes in urinary sediment. The representative serological profile early in her course included an antinuclear antibody titre of $1 / 640$ in a diffuse and speckled pattern, a positive ribonucleoprotein (RNP) titre of $1 / 4 \times 10^{6}$, an $S M$ titre positive at $1 / 64$, a latex fixation of $1 / 320$, a negative titre for antibodies to double stranded DNA, a normal initial C3, but $\mathrm{C} 4$ markedly reduced at $75 \mathrm{mg} / \mathrm{l}$. She was treated with salicylates and steroids, which resulted in clinical improvement despite a delay in growth with vertebral fractures and aseptic necrosis of the femoral head. Azathioprine was later added for disease control.

At 15 years of age an asymptomatic murmur was attributed to mitral valve prolapse, but no other abnormalities were seen by echocardiography. When she was 16 years old, one year after discontinuing azathioprine treatment and decreasing the dose of steroids, an intercurrent respiratory infection indicated pulmonary hypertension, for which the steroid dose was increased.

Physical examination showed a small girl with an immature appearance and Cushingoid features, weighing $34 \mathrm{~kg}$ and with a blood pressure of $105 / 85 \mathrm{mmHg}$. Her skin was taut and dry and she had small tapered fingers and toes. There was an area of chronic ischaemic changes on her right foot and ankle. There was no Homan's sign, no lymphadenopathy, and no hepatosplenomegaly. There was no jugular venous distension, clubbing, cyanosis or oedema. Her lungs were clear and pulses strong. The right ventricular impulse was increased; the second heart sound was palpable at the left upper sternal border and was loud and single. There was an early systolic apical click and an intermittent grade 2/6 apical mid to late systolic 'whooping' murmur, but no diastolic murmur.

An electrocardiogram showed a right axis deviation of $+120^{\circ}$ and non-specific $T$ wave changes, but no definite chamber hypertrophy. A chest radiograph showed a normal heart size but a dilated main pulmonary artery shadow and an enlarged right ventricle. The lung fields were clear. An echocardiogram showed a dilated right ventricle and pulmonary artery with evidence of pulmonary hypertension by time intervals and pulmonary flow velocity timing (table 1). There was holosystolic mitral valve prolapse without regurgitation.

Cardiac catheterisation (table 2) showed pulmonary hypertension at one third of systemic levels (aortic systolic pressure $115 \mathrm{mmHg}$, pulmonary $37 \mathrm{mmHg}$ ) and a low cardiac index $\left(2 \mathrm{l} / \mathrm{min} / \mathrm{m}^{2}\right)$, resulting in a pulmonary vascular resistance of $6 \mathrm{U} / \mathrm{m}^{2}$. The pulmonary artery pressure increased with exercise. Trials with oxygen, isoprenaline hydrochloride, and hydralazine showed that the last drug was the most efficacious and best tolerated vasodilator.

Further evaluation at the time of catheterisation showed a haemoglobin concentration of $91 \mathrm{~g} / \mathrm{l}$, an erythrocyte sedimentation rate of 120-140 $\mathrm{mm} /$ hour, white blood cell count $4-10 \times 10^{9} / 1$, and platelet count $101 \times 10^{9} / 1$. The protime was normal, but the partial thrombo- 
Table 1 Clinical data

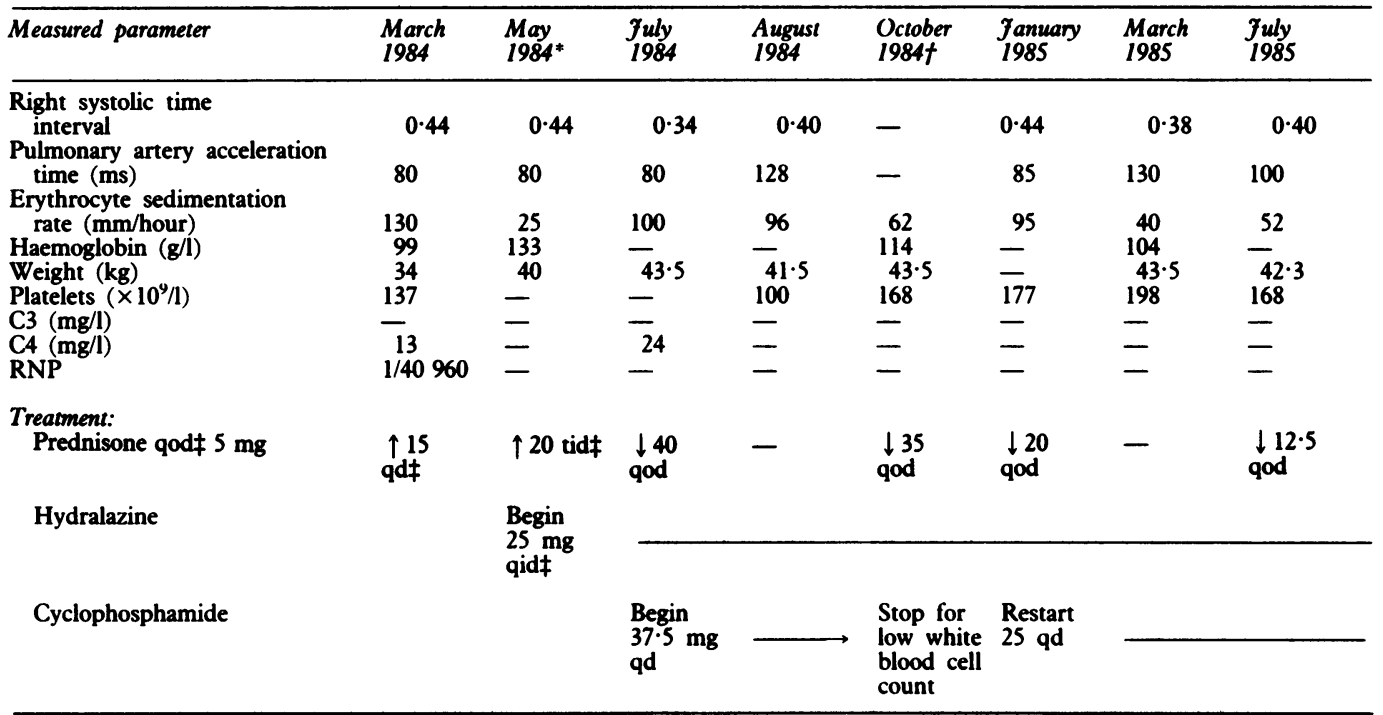

${ }^{*}$ Date of first catheterisation.

tDate of second catheterisation.

fqod=every other day; qd=every day; tid=three times a day; bid=twice a day; qid=four times a day.

Table 2 Catheterisation data

\begin{tabular}{|c|c|c|c|c|c|c|c|}
\hline & \multicolumn{5}{|c|}{10 May 1984} & \multicolumn{2}{|c|}{9 October 1984} \\
\hline & Rest & $100 \%$ oxygen & $\begin{array}{l}\text { Isoprenaline } \\
\text { hydrochloride }\end{array}$ & Hydralazine & Exercise & $\begin{array}{l}\text { Rest without } \\
\text { drugs }\end{array}$ & Hydralazine \\
\hline $\begin{array}{l}\text { Heart rate (beats/min) } \\
\text { Aortic pressure }(\mathrm{mmHg}) \\
\text { Aortic saturation }(\%) \\
\text { Aortic } \mathrm{Po}_{2}(\mathrm{mmHg}) \\
\text { Pulmonary pressure }(\mathrm{mmHg}) \\
\text { Pulmonary saturation }(\%) \\
\text { Pulmonary } \mathrm{Po}_{2}(\mathrm{mmHg}) \\
\text { Mean right atrial pressure (mmHg) } \\
\text { Mean pulmonary capillary }\end{array}$ & $\begin{array}{l}70 \\
115 / 75,95 \\
96 \\
89 \\
37 / 10,20 \\
60 \\
32 \\
3\end{array}$ & $\begin{array}{l}74 \\
105 / 75,88 \\
99 \\
430 \\
42 / 20,30 \\
70 \\
40 \\
3\end{array}$ & $\begin{array}{l}94 \\
105 / 68,75 \\
97 \\
95 \\
45 / 25,35 \\
63 \\
36 \\
8\end{array}$ & $\begin{array}{l}94 \\
95 / 70,82 \\
97 \\
96 \\
35 / 12,24 \\
68 \\
35 \\
3\end{array}$ & $\begin{array}{l}120 \\
110 / 88,102 \\
96 \\
\overline{48 / 30,} 40 \\
75 \\
-\end{array}$ & $\begin{array}{l}85 \\
125 / 85,100 \\
98 \\
98 \\
50 / 28,34 \\
69 \\
45 \\
3\end{array}$ & $\begin{array}{l}115 \\
100 / 72,85 \\
98 \\
95 \\
45 / 25,34 \\
75 \\
50 \\
3\end{array}$ \\
\hline $\begin{array}{l}\text { pressure (mmHg) } \\
\text { Oxygen consumption }\left(\mathrm{ml} / \mathrm{min} / \mathrm{m}^{2}\right)\end{array}$ & $\begin{array}{l}5 \\
124\end{array}$ & 4 & $\begin{array}{l}5 \\
206\end{array}$ & $\begin{array}{l}6 \\
181\end{array}$ & - & $\begin{array}{l}7 \\
145\end{array}$ & $\begin{array}{l}5 \\
128\end{array}$ \\
\hline $\begin{array}{l}\text { Arteriovenous oxygen difference } \\
\quad(\mathrm{ml} / \mathrm{dl}) \\
\text { Cardiac output }(\mathrm{l} / \mathrm{min}) \\
\text { Pulmonary vascular resistance }\left(\mathrm{U} / \mathrm{m}^{2}\right) \\
\text { Systemic vascular resistance }\left(\mathrm{U} / \mathrm{m}^{2}\right) \\
\text { PVR/SVR } \\
\text { Right systolic time interval (M mode) } \\
\text { Doppler acceleration time (ms) }\end{array}$ & $\begin{array}{l}4 \cdot 5 \\
2 \cdot 4 \\
6 \\
38 \\
0 \cdot 2 \\
0 \cdot 23 \\
80\end{array}$ & $\begin{array}{l}4.5 \\
= \\
= \\
=\end{array}$ & $\begin{array}{l}4 \cdot 4 \\
4 \cdot 7 \\
6 \\
14 \\
0 \cdot 4 \\
0 \cdot 38 \\
-\end{array}$ & $\begin{array}{l}3 \cdot 9 \\
4 \cdot 7 \\
3 / 8 \\
17 \\
0 \cdot 2 \\
0 \cdot 29 \\
80\end{array}$ & $\begin{array}{l}2 \cdot 8 \\
= \\
= \\
=\end{array}$ & $\begin{array}{l}4 \cdot 1 \\
4 \cdot 9 \\
5 \cdot 5 \\
20 \\
0 \cdot 3 \\
0 \cdot 40 \\
128\end{array}$ & $\begin{array}{l}3 \cdot 2 \\
5 \cdot 4 \\
4.9 \\
16 \\
0.3 \\
- \\
-\end{array}$ \\
\hline
\end{tabular}

$*$ Patient developed nausea, hypertension, and bradycardia.

plastin time was increased $43.9 \mathrm{~s}$ (control $32 \mathrm{~s}$ ), and a circulating anticoagulant was shown. A single urine sample revealed 4+ proteinuria with 5-10 red blood cells and white blood cells per high power field. Subsequent urine analysis, however, was normal and nephritis was not seen. Pulmonary function tests showed a moderate restrictive abnormality with normal diffusion, and gallium and ventilation/perfusion lung scans, and peripheral venous Doppler examination ruled out pulmonary emboli and deep vein thrombosis. A lung biopsy sample was not taken. Nailfold capillary microscopy showed dilatory changes of the scleroderma type. Serologies remained positive as before, with a low $\mathrm{C} 4$ and a positive titre for antiSSA (Ro). In the presence of pulmonary hypertension and active serologies, she was treated again with high dose prednisone, hydralazine was begun at $25 \mathrm{mg}$ four times a day by mouth, and cyclophosphamide was added for further immunosuppression.
Over the next four months she showed subjective and objective improvement on this drug regimen. The Doppler pulmonary artery acceleration time was still prolonged, but the $M$ mode right sided systolic time intervals decreased. Her sedimentation rate decreased from 120 to $25 \mathrm{~mm} /$ hour, and the steroid dose was tapered.

A repeat cardiac catheterisation five months after the first (table 2) showed persistent pulmonary hypertension (aortic systolic pressure $125 \mathrm{mmHg}$, pulmonary $50 \mathrm{mmHg}$ ) with a stable pulmonary vascular resistance of $5.5 \mathrm{U} / \mathrm{m}^{2}$. Acute drug testing showed persistent responsiveness to hydralazine with an increase in the cardiac index from 3.5 to $3.9 \mathrm{l} / \mathrm{min} / \mathrm{m}^{2}$. Therefore the regimen of corticosteroids, cyclophosphamide, and hydralazine was continued, in tapering doses, over the next four years. The course was complicated only by transient neutropenia and thrombocytopenia, associated with antibodies to platelets. 


\begin{tabular}{|c|c|c|c|c|c|c|c|c|}
\hline $\begin{array}{l}\text { October } \\
1985\end{array}$ & $\begin{array}{l}\text { February } \\
1986\end{array}$ & $\begin{array}{l}\text { May } \\
1986\end{array}$ & $\begin{array}{l}\text { fune } \\
1986\end{array}$ & $\begin{array}{l}\text { fuly } \\
1986\end{array}$ & $\begin{array}{l}\text { April } \\
1987\end{array}$ & $\begin{array}{l}\text { March } \\
1988\end{array}$ & $\begin{array}{l}\text { Mav } \\
1988\end{array}$ & $\begin{array}{l}M a y \\
1989\end{array}$ \\
\hline $0 \cdot 28$ & 0.29 & - & - & 0.30 & - & - & - & - \\
\hline 140 & 140 & - & - & 120 & - & - & 110 & - \\
\hline $\begin{array}{l}70 \\
115 \\
42 \cdot 7 \\
140 \\
= \\
=\end{array}$ & $\begin{array}{r}53 \\
115 \\
44 \\
134 \\
= \\
=\end{array}$ & $\begin{array}{l}60 \\
120 \\
= \\
= \\
=\end{array}$ & $\begin{array}{r}46 \\
128 \\
380 \\
73 \\
22 \\
-\end{array}$ & $\begin{array}{l}\bar{Z} \\
\overline{4} 2 \cdot 5 \\
\overline{-} \\
0\end{array}$ & $\begin{array}{c}46 \\
- \\
= \\
79 \\
9 \\
1 / 1280\end{array}$ & $\begin{array}{l}73 \\
= \\
-62 \\
29 \\
17 \\
1 / 10,240\end{array}$ & $\begin{array}{r}69 \\
130 \\
43 \\
- \\
43 \\
23 \\
-\end{array}$ & $\begin{array}{l}\overline{ } \\
\overline{111} \\
34 \\
19 \\
1 / 2560\end{array}$ \\
\hline$\underset{\text { qod }}{\downarrow 17.5}$ & $\begin{array}{l}\downarrow 5 \\
\text { qod }\end{array}$ & - & - & - & - & $\underset{q d}{\uparrow 40}$ & - & $\underset{q d}{\downarrow}$ \\
\hline & & & & & 25 & - & - & - \\
\hline
\end{tabular}

Discontinued
Discussion

Mixed connective tissue disease is an overlap syndrome of autoimmune disease with features resembling systemic lupus erythematosus, scleroderma, and dermatomyositis, but with a characteristic serological picture. ${ }^{2}$ Our patient showed various findings over a period of time, but her disease never evolved clearly into any of the other collagen vascular disease categories. Although some may argue that the intermittently positive titre for antiSm favours a diagnosis of lupus erythematosus, we felt her overall pattern best fitted the diagnosis of mixed connective tissue disease. This disease has a known tendency towards the development of pulmonary hypertension..$^{3-5}$ The pathophysiology is not fully known, but may be similar to that in primary pulmonary hypertension, a disease in which there is a high incidence of positive serologies for collagen vascular disease. ${ }^{8}$ Limited pathological studies in mixed connective tissue disease ${ }^{3}$ have shown features which are characteristic of pulmonary hypertension in general, including right ventricular hypertrophy, marked intimal proliferation, and medial hypertrophy of pulmonary arteries and arterioles. The part played by in situ thrombosis, as shown in pulmonary hypertension, ${ }^{10}$ has not been well defined in mixed connective tissue disease. ${ }^{5}$ This suggests, however, a possible role for the lupus anticoagulant, ${ }^{11}$ such as in our patient, in the origin or progression of this process. Although anticardiolipin antibodies may theoretically affect thrombosis, we were unable to measure them in our patient until 1988 , when they were normal.

Several additional clinical features deserve comment. During aggressive treatment, the cardiopulmonary improvement seemed to parallel the improved serological data and resolution of thrombocytopenia. Despite later serological and haematological relapses, which occurred as the drugs were tapered to less toxic levels, the pulmonary vascular remission was maintained.

Secondly, dilated nailfold capillary microscopy changes of the scleroderma type were seen in this patient. These findings are associated with pulmonary hypertension in mixed connective tissue disease. ${ }^{3}$ Finally, the patient had a well documented mitral valve prolapse, which disappeared as the disease came under control. This finding underlines the observed association between mitral valve prolapse and collagen vascular disease. ${ }^{12}$

Clinical evaluation of patients with pulmonary hypertension has generally required the use of serial invasive cardiac catheterisations to measure pulmonary artery pressure and flow. This is clearly not ideal for a sick child owing to its morbidity, discomfort, and cost. Improvements in the technology of ultrasound have provided a non-invasive serially applicable means of assessing the pulmonary pressure. The use of two dimensional echocardiography has shown the predictive value of flattening and posterior displacement of the interventricular septum toward the lumen of the left ventricle, indicating right ventricular hypertension. ${ }^{13} 14$ This finding is seen only with the more severe peak velocity of flow. An acceleration time of less than $100 \mathrm{~ms}$ was considered abnormal; 100 to $120 \mathrm{~ms}$ was borderline, and an acceleration time over 120 was considered normal. 67 
disease, however, and is difficult to quantitate. Although right sided systolic time intervals measured by $\mathbf{M}$ mode echocardiography to assess pulmonary pressures are non-invasive, they are not accurate. When combined with Doppler derived time intervals of pulmonary flow velocity, such as the accleration time, however, the predictive accuracy is improved, and a useful non-invasive assessment tool for pulmonary hypertension is available. ${ }^{6}$ These methods were used in this patient, and allowed less frequent invasive catheterisations to measure pulmonary pressure and resistance. This case is unique in that a new non-invasive technology was the key to diagnosis and serial evaluation of pulmonary hypertension in mixed connective tissue disease.

Treatment for pulmonary hypertension is empirical and usually unsuccessful. The underlying disease, if present, is treated, and in this instance included the vigorous use of steroids and antimetabolites. If thromboembolism is felt to play a part, then anticoagulants may be used. ${ }^{10}$ Attention has recently focused on the use of vasodilator drugs for short term clinical benefit, and perhaps for long term reversal of the underlying process. Classes of drugs include the direct vasodilators such as hydralazine, ${ }^{15} 16$ calcium channel blockers such as nifedipine, ${ }^{17}$ and prostaglandins such as prostacyclin. ${ }^{18}$ These drugs have had variable results. The patient in this study was treated with hydralazine, which during acute invasive drug testing was effective and was the better tolerated drug.

The prognosis of pulmonary hypertension is generally poor in most natural history studies, ${ }^{3}$ and not much improved even with the use of long term vasodilatation. ${ }^{19}$ Therefore, this patient is unusual in that, with aggressive vasodilatation and treatment of the underlying disease, subjective and objective evidence of recovery from pulmonary hypertension was achieved.

1 Perkin R M, Anas N G. Pulmonary hypertension in pediatric patients. $\mathcal{J}$ Pediatr 1984; 105: 511-22.
2 Singsen B H, Bernstein B H, Kornreich $\mathbf{H ~ K , ~ K i n g ~} \mathbf{K ~ K}$, Hanson V, Tan E M. Mixed connective tissue disease in childhood. A clinical and serologic survey. $\mathcal{F}$ Pediatr 1977; 90: 893-900.

3 Sullivan W D, Hurst D J, Harmon C E, et al. A prospective evaluation emphasizing pulmonary involvement in patients with mixed connective tissue disease. Medicine (Baltimore) 1984; 63: 92-107.

4 Singsen B H, Platzker A C G. Pulmonary involvement in the rheumatic disorders of childhood. In: Kendig E L, Jr., Chernick V, eds. Disorders of the respiratory tract in children. 4th ed. Philadelphia: Saunders, 1983: 863-5.

5 Jones M B, Osterholm $R$ K, Wilson R B, Martin F H, Commers J R, Bachmayer J O. Fatal pulmonary hypertension and resolving immune-complex glomerulonephritis in mixed connective tissue disease. Am $\mathcal{F ~ M e d ~ 1 9 7 8 ; ~ 6 5 : ~}$ 855-63.

6 Kitabatake A, Inoue M, Asao M, et al. Noninvasive evaluation of pulmonary hypertension by a pulsed Doppler technique. Circulation 1983; 68: 302-9.

7 Kosturakis D, Goldberg S J, Allen H D, Loeber C. Doppler echocardiographic prediction of pulmonary arterial hypertension in congenital heart disease. Am $\mathcal{F}$ Cardiol 1984; 53 : $1110-5$.

8 Rich S, Kieras K, Hart K, Groves B M, Stobo J D, Brundage B H. Antinuclear antibodies in primary pulmonary hypertension. F Am Coll Cardiol 1986; 8: 1307-11.

9 Fuster V, Steele P M, Edwards W D, Gersh B J, McGoon M D, Frye R L. Primary pulmonary hypertension: natural history and the importance of thrombosis. Circulation 1984 70: $580-7$.

10 Cohen M, Edwards W D, Fuster V. Regression in thromboembolic type of primary pulmonary hypertension during $21 / 2$ years of antithrombotic therapy. $7 \mathrm{Am}$ Coll Cardiol 1986; 7: 172-5.

11 Asherton A, Mackworth-Young G, Boey L, Hull G, Saunders S, Gharavi E, Hughes G R V. Pulmonary hypertension in systemic lupus erythematosus. $B M F$ 1983; 287: 1024-5

12 Comens S M, Alpert M A, Sharp G C, et al. Frequency of mitral valve prolapse in systemic lupus erythematosus, progressive systemic sclerosis and mixed connective tissue disease. Am 7 Cardiol 1989; 63: 369-70.

13 King $M$ E, Braun H, Goldblatt A, Liberthson R, Weyman A $\mathrm{E}$. Interventricular septal configuration as a predictor of right ventricular systolic hypertension in children: a crosssectional echocardiographic study. Circulation 1983; 68: 68-75.

14 Ryan T, Petrovic O, Dillon J C, Feigenbaum H, Conley M J, Armstrong W F. An echocardiopgraphic index for separation of right ventricular volume and pressure overload. $\boldsymbol{I} \mathrm{Am}$ Coll Cardiol 1985; 5: 918-24.

15 Rubin L J, Peter R H. Oral hydralazine therapy for primary pulmonary hypertension. N Engl F Med 1980; 302: 69-73.

16 Packer M, Medina N, Yushak M. Adverse hemodynamic and clinical effects of calcium channel blockade in pulmonary hypertension secondary to obliterative pulmonary vascular disease. I Am Coll Cardiol 1984; 4: 890-901.

17 Rich S, Brundage B H. High-dose calcium channel-blocking therapy for primary pulmonary hypertension: evidence for long-term reduction in pulmonary artery pressure and regression of right ventricular hypertrophy. Circulation 1987; 76: 135-41.

18 Bush A, Busst C, Booth K, Knight W B, Shinebourne E A. Does prostacyclin enhance the selective pulmonary vasodilator effect of oxygen in children with congenital heart disease? Circulation 1986; 74: 135-44.

19 Rich S, Brundage B H, Levy P S. The effect of vasodilator therapy on the clinical outcome of patients with primary pulmonary hypertension. Circulation 1985; 71: 1191-6. 